\title{
Få pasienten ut av offerrollen
}

Grenseløs empati fra sykepleiere kan gjøre personer med emosjonell ustabil personlighetsforstyrrelse sykere.

\section{Kathrine Benedikte Larsen}

Psykiatrisk sykepleier

Psykisk lidelse

\section{Hovedbudskap}

Pasienter med emosjonell ustabil personlighetsforstyrrelse tar gjerne på seg offerrollen. Grenseløs empati, stakkarsliggjøring og fritak fra ansvar for eget liv forsterker denne offerrollen og virker mot sin hensikt. 
«Jeg har marinert meg i egen selvmedlidenhet. På mange måter har det vært behagelig idet man alltid har en unnskyldning om man blir kritisert for sin atferd. Det var alltid jeg som hadde det verst. Da jeg endelig ble innlagt, fikk jeg bekreftelse på at jeg var mye sykere enn alle andre jeg kjente, og dette ble identiteten jeg trodde jeg søkte etter. Her fikk alle mine mønstre den perfekte grobunn til å blomstre. Som evig offer. Der opplevde jeg terapeuter som gråt da jeg fortalte om mine traumer, og de fortalte om hvor sterkt de $\varnothing$ nsket å hjelpe denne lille jenta. En drøm ble til virkelighet. Selv om jeg ikke visste det da, så brukte jeg min oppvekst for alt det var verdt.» Slik beskriver en pasient det å ha emosjonell ustabil personlighetsforstyrrelse (UPF) (1).

Pasienter med UPF kan ofte gi uttrykk for at de er «det evige offeret» og konstant utsatt for andres ondskap $(2,3,4)$. Samtidig lar andre mennesker seg ofte fengsle eller fascinere av denne offerrollen, da det er lett å bli fanget inn og føle at man forstår pasienten. I ytterste konsekvens kan det føre til at andre må betale for pasientens manglende autonomi $(4,5,6)$.

Wilhelmsen (1) hevder at man noen ganger kan gjøre pasienten en bjørnetjeneste med grenseløs ikkekonfronterende empati og «stakkarsliggiøring», noe som forsterker offerrollen - og dermed lidelsen. Budskapet i denne artikkelen er at å frata disse pasientene ansvar og dermed forsterke offerrollen, virker mot sin hensikt, noe som har bred støtte i litteraturen $(1,3,4,5,6,7)$.

\section{Offerrollen}


Dupont, gjengitt av Gabbard og Wilkinson (6), omtalte tidlig offerrollen som et drama med fire hovedpersoner: et offer, en krenker, en idealisert frelser og en uengasjert mor. Rollen som offer formes i barndommen og danner grunnlag for pasientens problematiske livsførsel senere i livet. Rollen kan likne på barnets hjelpeløshet, idet pasienten gjerne vil fraskrive seg ansvar for eget liv (1). Tendensen til å gi andre ansvaret for å holde seg i live, er et atferdsaspekt som blir karakterisert som et av de mest uheldige trekkene hos mennesker med UPF (4).

Fremstillingen av seg selv som offer kan ifølge Gabbard og Wilkinson (6) ha å gjøre med at pasienten verken kan ta ansvar for eller evner å se konsekvensene av sine handlinger og valg. Pasientene har også ofte en tendens til å bebreide seg selv ved å anta at de er dårlige mennesker.

I tillegg kan pasientene se verden på en negativ og ondartet måte. De har gjerne ikke opplevd klare grenser som har blitt håndhevet av kjærlige foreldre. De har opplevd, og opplever, at uansett hva de gjør, blir det ikke bedre. På mange måter er de fanget i en felle der ingenting kan endre deres skjebne (6). Dermed kan de drives av en stadig søken etter den eller det som skal lindre tomheten eller angsten, og som kan gi dem det perfekte livet $(4,6)$. En slik person er et idealisert overmenneske, som dessverre ikke finnes (3).

\section{«Jeg kan selv ha bidratt til å støtte opp under offerrollen til pasientene.»}


For en tid tilbake, som fersk sykepleier, hadde jeg store ambisjoner om å utøve omsorg på best mulig måte. Jeg begynte å jobbe på akuttpsykiatrisk avdeling, og kan selv ha bidratt til å støtte opp under offerrollen til UPF-pasientene. Jeg syntes så synd på dem. Og det var synd på dem, men jeg visste bare ikke at jeg ikke skulle overøse dem med betingelsesløs omsorg og pleie slik jeg hadde lært. «Jammen dette er jo stakkars syke mennesker», svarte jeg, og holdt den selvskadende jenta varsomt $\mathrm{i}$ hånden mens jeg trøstet henne. Skulle jeg ikke utøve sykepleie slik jeg hadde lært? Det var bare det at jo mer jeg ga av meg selv, jo mer ville de ofte ha. Jeg lærte heldigvis raskt at det var feil vei å gå å kaste meg ut i selvavsløringer eller å «gi alt» på den aktuelle vakten for å unngå selvskading de få timene vakten varte.

\section{Ansvar versus regresjon}

Ifølge Yrkesetiske retningslinjer for sykepleiere (8) «fremmer sykepleieren pasientens mulighet til å ta selvstendige avgjørelser». Norges offentlige utredninger (9) fremhever at ansvarliggjøring for og bistand til å ta ansvar for eget liv er sentralt hos pasienter med alvorlige personlighetsforstyrrelser.

Som nevnt innledningsvis kan UPF-pasienter i offerrollen fraskrive seg ansvar eller gjøre seg avhengig av sykepleieren. Ofte er det viktig for dem å få menneskene rundt seg til å ta del i sin egen lidelse og ulykke $(1,2,4,6)$. Samtidig kan sykepleierne føle at pasientene er berettiget til å få ekstra pleie og medfølelse. Pasientene kan hevde at de har krav på kompensasjon i nåtiden for de overgrepene de ble utsatt for i fortiden (6). Pasientene kan føle at alt er urettferdig, og de kan være utilgivelige overfor dem de mener har gjort dem ille. Ofte har de hjerteskjærende historier å fortelle. De vil gjerne tas hånd om som et lite barn, men ikke bli korrigert.

\section{«Ofte har pasientene hjerteskjærende historier å fortelle»}


UPF-pasientenes atferd, for eksempel når de truer med selvmord, hindrer ofte autonomien, fordi ansvaret for eget liv overlates til andre $(1,4,5)$. Faren er da regresjon, som vil si å gå tilbake til tidligere utviklingsstadier (10). Regresjon er menneskelig, men for personer med UPF stimuleres denne funksjonen lett, noe som er enkelt å forstå når man kjenner til bakgrunnen deres, som ofte er traumatisk (5). Med en uendelig tålmodig sykepleier trenger ikke pasienten forholde seg til de virkelige problemene i den virkelige verden (3).

Ifølge Evang (5) bør varsellampene lyse hvis sykepleieren er på vei inn i denne «frelserrollen» og opptrer som den forelderen pasienten aldri fikk. Paris (4) understreker at dette er uprofesjonelt og farlig, i og med at man kun har én mulighet til å være barn. Å gå tilbake til det stadiet som voksen er svært uheldig for personen.

I forlengelsen av dette påpeker Kåver og Nilsonne at ubetinget og kontinuerlig medfølelse ikke eksisterer i noen relasjon og er helt unaturlig (11). Vi må derfor være bevisste på at pasienten en dag skal klare seg alene - bli autonom, bli et subjekt og ikke et offer.

\section{Må stille krav}

Konsekvensene av overinvolvering kan være at pasienten ikke får den hjelpen vedkommende virkelig trenger, og dermed blir enda mer hjelpeløs og avhengig (12). Som et paradoks kan de som $\varnothing$ nsker mest å forandre pasienten og går inn i det med kropp og sjel, faktisk ha minst sannsynlighet for å hjelpe vedkommende med å bli frisk $(4,6)$. Nilson og Silfving understreker at hvis UPF-pasientene behandles som voksne mennesker, og sykepleieren stiller adekvate spørsmål og krever logisk resonnement, vil man kunne bidra til å ansvarliggjøre pasienten, samtidig som man fungerer som en positiv rollemodell (3). 
Kåver og Nilsonne (11) støtter dette synet og hevder at man ikke bare skal trøste, forstå og betrakte pasienten som skjør og stakkarslig, men som kompetent ved å konfrontere og lede vedkommende til forandring. Hvis ikke kan man støtte et feilaktig bilde av den virkelige verden og underbygge offerrollen.

Akuttpsykiatriske avdelinger kan virke forsterkende på offerrollen da mange pleiere og mange aktiviteter stimulerer fantasien om idealisert omsorg (5). Pasientene kan dermed få «sekundærgevinster» ved å være innlagt, noe man prøver å unngå fordi det kan være regresjonsfremmende. I tillegg kan pasientene kreve umiddelbar behovstilfredsstillelse i avdelingen, noe som kan henge sammen med forestillingen om at mor og barn danner en allmektig enhet som barnet kontrollerer (5).

Slik tilfredsstillelse er både urealistisk og kontraindisert $i$ avdelingen, og fremmer derfor ofte skuffelse og raseri. Trassig taushet og selvmordstrusler forekommer ofte som følge av dette, noe som igjen gjerne fører til flere restriktive tiltak, slik som kontinuerlig tilsyn, beltelegging og skjerming. Slik blir pasientene frarøvet sin autonomi og sitt ansvar, som er en uheldig utvikling og som fører dem inn i onde sirkler (4). Det er lett å omplassere skylden hvis tiltak ikke fører frem. «Vi får skjerme henne, det er det eneste som hjelper.» (13)

\section{Bør ikke overbeskyttes}


Noen ganger vegrer sykepleierne å gi UPF-pasientene mer ansvar fordi de er redde for at ting skal gå galt på avdelingen, som for eksempel selvskading, selvmordsfors $\varnothing \mathrm{k}$ med mer. Samtidig påpekes det at å «pakke pasientene inn i bomull» heller ikke er løsningen (15). Dette kan gjenkjennes i praksis, hvor man for eksempel kan skjerme pasienten eller «strippe» rommet og dermed sørge for at pasienten ikke finner noe å skade seg med. Istedenfor å gi pasienten ansvar, tar vi det fra vedkommende, noe som opprettholder den onde sirkelen (15). Innleggelse blir da et toegget sverd: Det som skal være en sikkerhet, blir det motsatte. Dermed får pasienten vanskeligheter med å klare seg alene når den tid kommer, noe som jo er målet.

Paris hevder langt på vei at det å overta pasientens ansvar for eget liv samt fokusere overdrevent på sikkerhet $\mathrm{i}$ akuttpsykiatrien i det lange $1 \varnothing p$, overhodet ikke er bra for pasienten. Han mener at risiko må kunne tolereres og at innleggelse helst ikke bør forekomme, da man står i fare for å stenge disse menneskene ute fra alt som er meningsfylt (4).

Nasjonale retningslinjer for selvmordsforebygging $\mathrm{i}$ Norge (16) henviser til samme resonnement i sine anbefalinger om at kronisk suicidale pasienter ikke bør legges inn i akuttpsykiatrien. Vi kan altså redde pasienten ved «ikke å redde» vedkommende (11).

\section{Må få mer ansvar}

Hummelvoll (17) understreker at det blir sykepleiernes vedvarende oppgave å oppmuntre og støtte pasienten når vedkommende blir mer selvstendig. Ved å gjenta for pasienten at hun eller han har valg, alternativer og ansvar, kan sykepleierne formidle håp og optimisme. En grunnholdning kan være å tro på og forvente at bedring vil skje. En slik innstilling krever tålmodighet, og det er viktig med en åpen og undrende holdning fremfor en dømmende (17). 


\section{«Ved å gjenta for pasienten at hun eller han har valg, alternativer og ansvar, kan sykepleierne formidle håp og optimisme.»}

I praksis kan det dreie seg om at pasientene får ansvaret for å velge hva de vil gjøre, enten det dreier seg om å delta på aktiviteter eller annet. Videre kan sykepleieren fremme denne evnen til selvstendighet ved å la pasienten utføre ting på egen hånd, som å ta nødvendige telefoner eller fylle ut søknader. På den måten kan man verne om de ressursene pasienten allerede innehar. Når pasienten klarer å utføre noe som er positivt for seg selv, er det viktig å rose vedkommende (5).

På den andre siden hevder Anstorp (12) at det akuttpsykiatriske personalet ofte fokuserer overdrevent på ansvaret for eget liv, noe som kan forsterke redsel og usikkerhet hos pasientene. Hun understreker at dersom UPF-pasientene hadde hatt mulighet til å takle ting på en selvstendig måte, hadde de gjort det.

\section{Vegrer seg for ansvar}

Man kan også stille spørsmål ved hvorvidt det er behagelig for pasienten å slippe å ta ansvar.

Erfaringsmessig kan det ofte oppfattes slik, noe som er forståelig. Avdelingen rammer pasientene inn $\mathrm{i}$ strukturer og regler og tar avgjørelser over hodet på dem for å sørge for at de i hvert fall holdes i live mens de er innlagt. Da kan det kanskje føles ekstra vanskelig å slippe ut i den store verden igjen alene, og med hele ansvaret hvilende på egne skuldre. Noen kan av den grunn lengte tilbake til ansvarsfraskrivelsen. 
Evang (5) hevder at pasientene vegrer seg for ansvar på grunn av dårlig utviklete egoer, funksjoner og dermed manglende evne til selvstendighet. Ekte selvstendighet er frihet til å bruke seg selv til fulle (5). Sykepleieren $b ø r$ derfor være sannferdig, synlig og forutsigbar. Det nytter ikke å late som om man bryr seg; man må vise ekte interesse og troverdighet (5). For pasienten er det derfor avgjørende å se at noen holder ut med vedkommende, er overbærende med affektene og kan gjøre følelsene mindre uutholdelige (6).

Nilson og Silfving (3) understreker at det alltid bør være atferden som skal konfronteres, aldri personligheten. Kunsten er å forklare hva som aksepteres og forventes på en saklig måte uten å være nedvurderende eller anklagende. De legger vekt på at sykepleierne må tørre å være nærværende uten samtidig å bli for personlig berørte, men alltid med bekreftende og respektfull undertone (3).

\section{Se sammenhengen}

Antonovsky (18) fremhever det å se pasienten som en helhet og noe mer enn delobjekter. Mestring $\mathrm{i}$ hverdagen beskrives som «opplevelse av sammenheng», eller salutogenese, der det fokuseres på det friske og det som kan utvikles hos mennesket. Han fant tre kjennetegn hos mennesker som har lyktes i å utvikle en positiv grunnholdning til tross for store påkjenninger: forståelse, håndterbarhet og opplevelse av mening. Sammenfattet kan disse tre aspektene forstås som opplevelse av sammenheng (18).

\section{«Kanskje bør man lete etter elementer i pasienten som er friske og sunne, for de finnes alltid.»}

I tråd med Antonovsky fremhever Paris (4) at UPFpasientene $b \varnothing r$ strebe etter å finne noe meningsfylt i tilværelsen for å kunne komme seg videre. Men kanskje er det nettopp slik at disse menneskene ofte ikke har noe meningsfylt å gå til? Det å bli frisk betyr ikke mye om man ikke har et liv å gå tilbake til (4). Kanskje bør man lete etter elementer i pasienten som er friske og sunne, for de finnes alltid. 
Paris (4) understreker også viktigheten av å appellere til pasientens friske sider. Hvis sykepleieren viser pasienten at noe friskt finnes, og at de har tro på det, kan det føles meningsfylt. Salutogenesen kan i tillegg også bidra til at pasienten forstår sammenhengen i sitt eget liv og hvorfor ting har blitt som de er. Erfaringsmessig fokuserer ofte pasienter med UPF på alt som har gått galt i livet. Det er vanskelig å se fremover om de dveler for mye ved det vonde, eller om de bruker fortiden sin som «hvilepute» og gir den skylden for at de aldri kommer seg videre.

Dette synet støttes av Paris (4), som understreker at her og nå-situasjonen er viktigere enn å jobbe seg gjennom barndomstraumer. I forlengelsen av dette hevder Wilhelmsen (1) at hvis man er offer for traumer eller er bitter og ikke vil ta ansvar, kan man bli offer for et nytt overgrep, denne gangen fra seg selv.

\section{Konklusjon}

Denne artikkelen har vist at det å frata ansvar og forsterke UPF-pasientens offerrolle er en uhensiktsmessig strategi som kan opprettholde og forverre pasientens infantile forventninger og regresjonstendens. Det er derfor viktig å holde fast ved de rammene avdelingen har samt stille krav om ansvarlighet og fremme selvstendighet for UPFpasientene. Det finnes også holdepunkter for å hevde at det er mer hensiktsmessig for disse pasientene å fokusere på nåtiden og fremtiden enn å leve i fortiden.

LES OGSÅ: Når pasienten vekker det verste i deg

\section{Referanser}

1. Wilhelmsen I. Det er ikke mer synd på deg enn andre. - En bok om ansvar og frigjøring. Stavanger: Hertervig Forlag. 2012.

2. Moskovitz R. Lost in the mirror. An inside look at Borderline Personality Disorder. Maryland: Taylor Trade Publishing. 2001. 
3. Nilson G, Silfving T. Farlige relationer - om

borderline. København: Nordisk Forlag. 2002.

4. Paris J. Half in love with death. Managing the chronically suicidal patient. Lawrence Erlbaum Associates Inc. 2007.

5. Evang A. Utvikling, personlighet og borderline. Oslo: Cappelen Damm. 2012.

6. Gabbard GO, Wilkinson SM. Borderline behandling og modoverføring. København: Hans Reitzels Forlag. 1996.

7. Henriksen JO, Vetlesen AJ. Nærhet og distanse. Grunnlag, verdier og etiske teorier i arbeid med mennesker. Oslo: Gyldendal Norsk Forlag. 2011.

8. Yrkesetiske retningslinjer for sykepleiere ICNs etiske regler. Kap. 2.2.4. Tilgjengelig fra: https://www.nsf.no/vis-artikkel/776377/NSFs-reviderteyrkesetiske-retningslinjer-2011-og-ICNs-etiske-regler. (Nedlastet 03.02.2017).

9. Norges offentlige utredninger (NOU) (2011: 9). $\varnothing \mathrm{kt}$ selvbestemmelse og rettssikkerhet. Balansegangen mellom selvbestemmelsesrett og omsorgsansvar i psykisk helsevern. Oslo: Helse og omsorgsdepartementet. 2011. Tilgjengelig fra: https://www.regjeringen.no/no/dokumenter/nou-20119/id647625/. (Nedlastet 03.02.2017).

10. Karterud S, Wilberg T, Urnes $\varnothing$. Personlighetspsykiatri. Oslo: Gyldendal Norsk Forlag. 2011.

11. Kåver A, Nilsonne A. Dialektisk atferdsterapi ved emosjonell ustabil personlighetsforstyrrelse. Oslo: Gyldendal Norsk Forlag. 2009.

12. Anstorp T, Benum K, Jakobsen M. Dissosiasjon og relasjonstraumer. Integrering av det splittede jeg. Oslo: Universitetsforlaget. 2012. 
13. Bøe TD, Thomassen A. Fra psykiatri til psykisk helsearbeid. Om etikk, relasjoner og nettverk. Oslo: Universitetsforlaget. 2010.

14. Stroud J, Parsons R. Working with borderline personality disorder: A small-scale qualitative investigation into community psychiatric nurses' constructs of borderline personality disorder. Personality and Mental Health 2013;7:242-53.

15. Larsen, K. «Bare gå og heng deg, din jævla dritt!!» Motoverføring og suicidalitet.

16. Nasjonale retningslinjer for forebygging av selvmord i psykisk helsevern. Tilgjengelig fra fra: https://helsedirektoratet.no/retningslinjer/nasjonalfaglig-retningslinje-for-forebygging-av-selvmord-ipsykisk-helsevern. (Nedlastet 14.02.2017).

17. Hummelvoll JK. Helt - ikke stykkevis og delt. Psykiatrisk sykepleie og psykisk helse. Oslo: Gyldendal Akademisk. 2012.

18. Antonovsky A. The salutogenetic model as a theory to guide health promotion. Tilgjengelig fra: https://www.sizediversityandhealth.org/images/upload ed/Health\%2oPromot.\%20Int.-1996-ANTONOVSKY11-8-1.pdf. (Nedlastet 14.02.2017). 